\title{
Recognizing the importance of nutrition counseling for the elderly with COPD in primary care
}

\author{
Mateja Šimec \\ University of Novo mesto, Faculty of Health Sciences, Novo mesto, Slovenia \\ mateja.simec@uni-nm.si
}

\begin{abstract}
Introduction: Chronic obstructive pulmonary disease (COPD) alters a person's metabolic processes and increases the need for energy and protein intake, while metabolism and muscle wasting are also affected by the aging process. A patient with COPD is at risk of malnutrition, therefore the medical staff in the family practise also plays an important role in the orderly and well-managed disease. Methods: The studyh was based on a qualitative approach, the method of description. A semistructured interview template was used as a measurement tool to collect data for the empirical part of the study. The study was conducted among nurses and paramedics at a health center. There were 7 participants in the stusy who are involved in the treatment of COPD patients. Results: The study revealed that the respondents' perception of the importance of nutritional counseling for older adults with COPD was low, which was reflected in the inadequate information provided to COPD patients on appropriate nutrition for their disease. The findings of the study also revealed that the respondents were aware of their role as health educators in the management of COPD patients, but self-assessment to have inadequate knowledge about proper nutrition in COPD, citing lack of opportunities to attend training on the subject. Discussion and conclusion: Weight loss in a COPD patient is associated with an increased risk of complications and mortality. Therefore, it is critical to identify older adults COPD patients because of the dangers associated with malnutrition and to recognize those with a pre-existing condition. Nutritional support (alongside appropriate physical activity) is the foundation for quality rehabilitation of patients with COPD, with a key role played by competent healthcare professionals involved in the comprehensive management of patients with COPD.
\end{abstract}

Keywords: COPD, nutrition, health education, patient 


\section{Introduction}

Chronic obstructive pulmonary disease (COPD) is an incurable, progressive, not fully reversible disease that most commonly affects smokers. It is a chronic inflammatory obstruction of the small airways characterized by an accelerated decline in lung function and premature death. In Slovenia, approximately 500 to 600 people die each year as a result of COPD (Šuškovič et al., 2011). According to the World Health Organization, the disease is the fourth leading cause of death (Kristan Škrgat et al., 2009). COPD patient has chronic bronchitis and a feeling of heavy breathing, mucus secretion increases, breathing mechanics are impaired, resulting in a feeling of heavy breathing, which is exacerbated during physical exertion. According to a European study, $73 \%$ of people with severe COPD suffer from dyspnea, $64 \%$ from sputum, $59 \%$ from cough and $42 \%$ from wheezing (Burkhardt and Pankow, 2014). The disease has a chronic course with accompanying acute exacerbations. Early detection and treatment of the disease has implications for slower disease progression and better quality of life (Škrgat et al., 2017). COPD is a major health problem as it is a leading cause of morbidity and mortality in developed and developing countries and is not only a respiratory disease, but is characterized by systemic inflammation that can manifest itself through skeletal and cardiac involvement: muscle wasting, cachexia, anemia and accelerated atherosclerosis (Šorli, 2015).

The main goals of COPD treatment are to prevent disease progression, relieve disease symptoms, increase physical capacity, prevent and treat disease exacerbations, and improve the patient's quality of life. Among the important non-pharmacological treatment measures is proper nutrition (regular meals, more protein in the diet, sufficient fluids) (Škrgat et al., 2017).

\section{COPD patient and diet}

Despite great advances in medicine, COPD still cannot be completely cured with available medications, so treatment is usually symptomatic. Patients are advised to change their lifestyle with the help of appropriate medications. This certainly includes proper diet, which can have a significant impact on relieving the symptoms of shortness of breath. COPD patients have on average $20-50 \%$ higher energy requirements, which is why they are advised to eat foods rich in energy and nutrients, as the energy consumption in the respiratory process is even ten times higher than usual in COPD patients, which should be taken into account when determining the appropriate daily caloric intake. About 40$50 \%$ of patients with advanced COPD suffer from weight loss, especially lean muscle mass (Samaras et al., 2015).

Inadequate energy and nutrient intake leads to patient malnutrition, metabolic changes, and progressive lung disease to pulmonary cachexia, which is associated with increased mortality in patients with COPD. Frequent fatigue can lead to loss of appetite, chronic airway inflammation from coughing can affect the smell and taste of food, and accompanying depression further reduc- 
es the patient's need for regular food intake. A rapid feeling of fullness after a meal causes the diaphragm to flatten, constricting the abdominal organs and increasing pressure in the stomach. Chronic cough with cough and shortness of breath further increases energy consumption and promotes malnutrition (Širca Čampa, 2016).

In COPD patients, protein and energy malnutrition and weight loss are permanent and even more rapid during exacerbations, and the main causes are anorexia and increased metabolic activity of the body. A COPD patient's diet should maintain proper nutrition and improve well-being because patients lose weight due to increased respiratory muscle function and energy expenditure, while less physical activity and poor patient nutrition decrease muscle mass and contractility of respiratory muscles. The goals of nutritional support are to ensure adequate nutrient intake according to individual energy needs, and to prevent weight loss, daily supplements in the form of oral energy drinks with high protein content should be included in the daily diet in addition to inadequate daily energy intake (Košnik et al., 2011).

\section{Family doctor and COPD patient}

The general practitioner (GP) is responsible for the diagnosis of COPD, health care management and referral to a specialist (Kristan Škrgat et al., 2009). In the primary care referral clinic, a graduate nurse performs preventive measures and manages specific groups of patients with chronic diseases, including COPD. Smokers and ex-smokers over the age of 40 are actively sought out, and a known COPD patient is seen once a year by a team in a GP referral clinic. Patients with suspected COPD are managed according to a predetermined protocol that includes the use of a standard questionnaire and guidelines for action based on the outcome (Susuč Poplas et al., 2013). The biggest problem of a COPD patient suffering from nutrition is protein-energy malnutrition, which can develop with increased energy and nutrient needs due to impaired lung function on the one hand and poor appetite of the patient on the other (Mahan, 2011), and non-pharmacological treatment of COPD includes advice on proper nutrition in addition to advice on smoking cessation, vaccination and rehabilitation (Škrgat, 2017).

The aim of this study was to determine the importance of nutritional advice for elderly patients with COPD in primary care. For this purpose, we asked the following research questions:

What is the perceived importance of nutritional counseling for older people with COPD in primary care?

What is the nature of nutritional counseling for older patients with COPD in primary care? 


\section{Methods}

The study was based on a qualitative research method. Primary and secondary sources were collected, analyzed and synthesized for the empirical work. Primary data for the analysis was obtained using the interview technique. For the theoretical part, technical and scientific literature from international databases in the field of nutrition of patients with COPD was used.

A semi-structured interview questionnaire was prepared for the study based on a review of domestic and foreign literature (Benedik, 2012; Širca Čampa, 2016; Vrbica, 2019). The first part of the questionnaire is related to demographic data and the second part is related to research. The survey was conducted in February 2021 among 7 nurses of the health center involved in the treatment of COPD patients. Participation in the survey was voluntary, and participants were informed in advance of the purpose of the survey. The interview was recorded using a recording device, and a verbatim transcript of the audio recording was made and sent to the respondents for approval. Codes and categories were established. We recorded the results in the discussion section. Ethical research principles were followed at all stages of data collection and processing.

\section{Results}

7 respondents were included in the survey; 5 nurses and 2 graduate medical technician aged between 21 and 46 years.

We have usefully divided the codes into categories:

- Category 1: Nutritional advice consists of the codes: inhaled drugs, not relevant, less necessary, medicines, elderly patients.

- Category 2: Patient information is characterized by codes: no advice, a little explanation, sometimes or rarely I say, they know too little.

- Category 3: Health worker's role in health education is characterized by codes: explanation, healthy lifestyle, educate older patients, advise on healthy eating

- Category 4: Health professionals' knowledge about nutrition of COPD patients is characterised by the following codes: I know too little, I don't know the guidelines, healthy eating pyramid, I follow the news, I'm interested, more protein.

- Category 5: Health worker education is made of codes: heard at Golnik, no education, COPD school, insufficient education, not relevant

\section{Discussion}

We found that a low perception of the importance of nutritional advice was prevalent among the study participants, which is unfavorable for patients 
with COPD, as Mahan et al. (2011) found that the major nutritional problem in COPD patients is protein-energy malnutrition, which can develop with increased energy and nutrient requirements due to patients' impaired lung function and lower appetite. Collins et al. (2013) state that disease-related malnutrition is a major problem in $30-60 \%$ of COPD patients, so it is important to identify these patients and counsel them appropriately on how to eat.

A worrying figure shows that patients in primary care are poorly informed about the importance of proper nutrition in their lung disease, as our study found that COPD patients receive very little information from primary care providers, especially if they do not report any occupations. Green and Watson (2005) emphasize that nurses have close contact with patients and play a key role in assessing patients' nutritional status and identifying malnourished patients who need additional advice and support in planning and implementing appropriate nutrition. Numerous studies suggest that targeted individualized nutritional therapy for COPD patients is important in all patients, not just malnourished patients with advanced COPD and reduced muscle mass, and should be part of the regular rehabilitation of these patients (Sugawara, 2015).

The GP referral clinic also cares for patients with regulated COPD and treats deterioration in the health of these patients (Škrgat et al., 2017), and through patient medical history taking we should identify COPD risk patients (malnourished patients and those close to it) and involve them in counseling on the importance of adequate nutrition or refer them to a dietitian who will help the patient to establish a diet plan and perform a nutritional assessment. The role of graduate nurse in independent patients in need of health education is to control the disease, which we believe includes counseling about appropriate nutrition. In the family medicine reference clinic patient must be motivated to learn about COPD, the nature of the disease, the effects of smoking, proper breathing, proper use of medications, the effects of respiratory rehabilitation, the expected course of the disease, and the importance of nutrition in COPD. Patients must be strongly encouraged to eat properly and prepare appropriate meals, and the patient's mental state should also be checked, as depression often develops, which affects nutritional status (Bratkovič, 2011).

The research found that the majority of COPD patients are advised by health professionals at the primary care level about proper nutrition for their lung disease. We believe that all COPD patients should receive at least basic advice on proper nutrition and adequate intake of nutrients, especially protein, at the initial level of medical care. Protein found in meat, milk, and dairy products is a rich source of protein that is important for maintaining muscle mass in COPD patients, and they need to consume it daily, regularly, and in sufficient amounts because, as Baum et al. (2016) note, problems that accompany patients with COPD (decreased appetite, poor taste perception, nausea) often prevent adequate intake of nutrients, especially protein. Metabolic changes in old age also affect the need for micronutrients, making it necessary to provide an adequate amount of vitamins (D, B12, B6, E and C) and minerals (calcium, 
iron, zinc) (NIJZ, 2016). With the aggravation of COPD, body weight decreases rapidly, so good nutrition and attention to a regular and proper diet are very important. Outpatient screening at the primary health care level can contribute significantly to the detection of patients with COPD (Yawn et al., 2014), so we believe it is useful to assess the nutritional status at the primary health care level with the questionnaire "The Mini Nutritional Assessment « (MNA) with anthropometric measurements and bioimpedance measurements. According to Širca Čampa (2016), the basic nutritional problem is not only energy malnutrition, but also protein malnutrition, which leads to inadequate nutrient ratios (excessive carbohydrate content in the diet), which is why nutritional support for patients with COPD is an important part of a holistic therapeutic approach. Symptoms of the disease, improving quality of life and slowing the progression of the disease.

This study is important because it gives us insight into the non-pharmacological treatment of COPD patients in the area of nutrition at the primary level of health care. COPD is a serious health problem and is one of the major causes of morbidity and mortality in both developed and developing countries, so proper treatment of COPD patients is essential. It is advisable to pay attention to proper nutrition as chronic lung patients tend to lose weight which is bad. The life of COPD patients with below average weight is shorter than that of normal weight patients because the muscles that are important for breathing function worse. Our study has also shown that the participants in the study are not able to acquire the necessary knowledge in organized trainings (continuously), and the question remains why the staff does not receive more training on the importance of proper nutrition of patients with COPD.

\section{Conclusions}

At the primary level of health care, more intensive counseling on appropriate nutrition is needed in all COPD patients, especially the elderly. This obviously requires the employment of health professionals with appropriate skills and sufficient up-to-date knowledge in this area, as COPD patients often do not meet health professionals until the primary care level and it is all the more important that they already receive appropriate health education. work in the area of nutrition in COPD which can make a significant contribution to their quality of life.

\section{References}

BAUM, J.I., KIM, IL, Y. and WOLFE, R.R., 2016. Protein Consumption and the Elderly: What Is the Optimal Level of Intake? Nutrients, vol. 8, no. 6, pp. 359.

BENEDIK, B., 2012. Stanje prehranjenosti in telesna sestava bolnikov s KOPB. Magistrsko delo. Univerza v Mariboru, Fakulteta za zdravstvene vede. 
BRATKOVIČ, M., 2011. Zdravstvena vzgoja bolnikov s KOPB - Šola KOPB na Kliniki Golnik. Modul: Astma, KOPB, Alergijski rinitis. Program za medicinske sestre in zdravstvene tehnike, Golnik, 5.-11. maj 2011. Golnik: Univerzitetna klinika za pljučne bolezni in alergijo; pp. 49-51. Dostopno na: http://www.klinika-golnik.si/strokovnajavnost/referencne-ambulante/datoteke/prirocnik_RA_2011a.pdf (8.2.2021).

BURKHARDT, R. in PANKOW, W., 2014. The diagnosis of cronic obstructive pulmonary disease. Deutsches Arzteblat International, vol. 111, no. 49, pp. $834-845$.

COLLINS, P.F., ELIA, M. and STRATTON, R.J., 2013. Nutritional support and functional capacity in chronic obstructive pulmonary disease: a systematic reviwe and meta-analysis. Respirology, vol. 18 (no. 4): pp. 616-629.

GREEN, S.M. and WATSON, R., 2005. Nutritional screening and assessment tools for use by nurse: literature review. Journal of Advanced Nursing, vol. 50, pp. 69-83.

KOŠNIK, M., MREVLJE, F., ŠTAJER, D., KOŽELJ, M. and ČERNELIČ, P., 2011. Interna medicina, 4. izdaja. Ljubljana: Littera picta - Slovensko medicinsko društvo, pp. 758-76o.

KRISTAN ŠKRGAT, S., ŠIFRER, F., GUČEK KOPČAVER, N., OSOLNIK, K., ERŽEN, R., FLEŽAR, M., PETEK, D., ŠORLI, J. ML., TOMIČ, V., MUŠIČ, E. et al. 2009. Stališče do obravnave akutnega poslabšanja KOPB, Zdravniški vestnik; vol. 78: pp. 19-32.

MAHAN, K.L. and RAYMOND, J.L., 2017. Krause's Food and the Nutrition Care Process. 14th Edition. Elsevier, St. Louis, London.

NIJZ - Nacionalni inštitut za javno zdravje, 2016. Referenčne vrednosti za energijski vnos hranil: tabelarična priporočila za otroke (od 1. leta starosti naprej), mladostnike, odrasle, starejše, nosečnice ter doječe matere [online]. [viewed 8. Februar 2021]. Available from: http://www.mz.gov.si/ fileadmin/mz.gov.si/pageuploads/javno_zdravje_2015/foto_DJZ/prehrana/2016_referencne_vrednosti_za_energijski_vnos_ter_vnos_hranil_17022016.pdf

SAMARAS, N., SAMARAS, D., CHAMBELLAN, A., PICHARD, C. and THIBAULT, R., 2014. Pulmonary rehabilitation: the reference therapy for undernourished patients with chronic obstructive pulmonary disease. Biomed Research International. 3:248420. doi: 10.1155/2014/248420. Epub 2014 Feb 19. PMID: 24701566 ; PMCID: PMC3950477.

SUGAWARA, K., TAKAHASHI, H., KASHIWAGURA, T., YAMADA, K., YANAGIDA, S., HOMMA, M., DAIRIKI, K., SASAKI, H., KAWAGOSHI, A., SATAKE, M., et al., 2012. Effect of anti-inflammatory supplementation with whey peptide and exercise therapy in patients with COPD. Respiratory Medicine, vol.106, no. 11, pp. 1526-1534.

SUSUČ POPLAS, T., ŠVAB, I. in KERSNIK, J., 2013. Projekt referenčnih ambulant družinske medicine v Sloveniji, Zdravniški Vestnik vol. 82: pp. 635647. 
ŠIRCA ČAMPA, A., 2016. Pomen dobre prehranjenosti bolnikov s KOPB. V: PRESTOR, L. eds. Astma in kronična obstruktivna bolezen,.Ljubljana: Zbornica zdravstvene in babiške nege Slovenije - Zveza društev medicinskih sester, babic in zdravstvenih tehnikov Slovenije, Sekcija medicinskih sester in zdravstvenih tehnikov v pulmologiji. pp. 137-145.

ŠKRGAT, S., TRILLER, N., KOŠNIK, M., POPLAS SUSIČ, T., PETEK, D., VODOPIVEC JAMŠEK, V., HUDOKLIN, I., OGRIČ LAPAJNE, A., LETONJA, S., ŠORLI, J. et al. 2017. Recommendations for the management of patients with chronic obstructive pulmonary disease (COPD) at primary and specialist pulmonary levels in Slovenia. Zdravstveni vestnik; vol. 86 (no. 1-2): pp. 65-75.

ŠORLI, J., 2015. Rehabilitacija je edini nujni del zdravljenja KOPB. Pharmonia. vol.13: pp. 13-14.

ŠUŠKOVIČ, S., 2011. Bolezni dihalnih poti. In: KOŠNIK, M., MRAVLJE, F., ŠTAJER, D., ČRNELČ, P., KOŽELJ, M., ANDOLJŠEK, D., eds. Interna medicina. Ljubljana: Littera Picta, d. o.o., Slovensko medicinsko društvo.

VRBICA, Ž., 2019. Prehrana bolnikov s KOPB. [online]. [viewed 10. Februar 2021]. Dostopno na: https://www.plivazdravlje.hr/aktualno/clanak/32069/Prehrana-bolesnika-oboljelih-od-KOPB-a.html

YAWN, B.P., DUVALL, K., PEABODY, J., ALBERS, F., IQBAL, A., PADEN, H., ZUBEK, V.B. in WADLAND, W.C., 2014. The impact of screening tools on diagnosis of chronic obstructive pulmonary disease in primary care. American Journal of Preventional Medicine, vol. 47 (no. 5): pp. 563-575. 